DOI: $10.37190 /$ epe 170206

\author{
YASEMIN İLHAN TUNALI ${ }^{1}$, SUNA ERTUNÇ ${ }^{1}$
}

\title{
USE OF NATURAL SODA ASH PRODUCTION PROCESS WASTE FOR $\mathrm{SO}_{2}$ REMOVAL
}

\begin{abstract}
Results of $\mathrm{ChemCad}^{\odot} 6.0$ simulation have been presented on usability of natural soda ash production process waste in order to remove $\mathrm{SO}_{2}$ from flue gas. Properties and concentrations of the solutions used in this study belong to the waste stream of Eti Soda Inc., and the flue gas compositions were acquired from an existing thermal power plant. $\mathrm{SO}_{2}$ and $\mathrm{H}_{2} \mathrm{O}$ feed rates and flue gas entrance temperature to the absorption tower were optimized through the response surface methodology (RSM) in order to attain highest $\mathrm{SO}_{2}$ removal yields. It has been found that $\mathrm{SO}_{2}$ removal remained at $33.83 \%$ when the waste composition was lower than 2 wt. \% while $100 \% \mathrm{SO}_{2}$ removal was reached as the waste composition was increased to 8 wt. $\%$. This result clearly demonstrates that treatment of natural soda ash production process waste can be done safely and economically while serving as an $\mathrm{SO}_{2}$ removal agent at the same time.
\end{abstract}

\section{INTRODUCTION}

World energy demand continuously grows up every passing day due to industrial and technological developments. New and renewable energy resources with more emphasis on fuel economy are needed to meet this growing demand without neglecting to establish better and efficient use of coal as the present and more abundant resource of energy. Lignites having high sulfur contents, when burned without preventive measures, produce sulfur dioxide $\left(\mathrm{SO}_{2}\right)$ which contributes most to the air pollution released to the atmosphere and causes many drawbacks for the living beings such as health problems and life quality [1]. Although $73 \%$ of the $\mathrm{SO}_{2}$ emission originates from thermal power plants using fossil fuels and $20 \%$ comes from industrial systems, it is well known that household heating and transportation also contribute to elevated $\mathrm{SO}_{2}$ levels in the atmosphere [2, 3]. It is unavoidable to have some obligations for the emission and removal of $\mathrm{SO}_{2}$ originating from thermal power plants. Abiding the emission limits given in related regulations in terms of environmental pollution prevention policies as well as requirements of environmental technologies increase the importance of $\mathrm{SO}_{2}$ removal from flue gas.

${ }^{1}$ Ankara University, Engineering Faculty, Chemical Engineering Department, 06100, Tandogan, Ankara, Turkey. Corresponding author S. Ertunç, e-mail address: ertunc@eng.ankara.edu.tr 
Various procedures have been reclaimed to decrease $\mathrm{SO}_{2}$ emission. Besides the primary techniques such as fuel enhancement and adsorption of $\mathrm{SO}_{2}$ in the combustion chamber [4], there exist many different widely utilized secondary approaches to remove $\mathrm{SO}_{2}$ from the flue gas by absorbing in wet and dry systems using ammonium, organic solvents and sea water as the sorbents $[5,6]$. Current research on flue gas desulfurization by dry techniques has focused on new and original sorbents to control $\mathrm{SO}_{2}$ emission $[7,8]$. On the other hand, research on wet desulfurization techniques concentrated on design of absorption columns having higher capacities and better dehydrating performances with substantially lower pressure drops $[9,10]$ as well as on modeling studies using industrial desulfurization process data for validation [11]. Besides the reports on flue gas desulfurization using trona as the sorbent as well as evaluating its $\mathrm{SO}_{2}$ absorption efficiencies and reaction mechanism, it is likely to come across some contributions assessing the effects of gas temperature, stoichiometric ratio and concentration of trona solution on $\mathrm{SO}_{2}$ removal in spray dryers by comparing experimental data with modeling results [12]. On the other hand, process modelling, design and optimization using various simulation programs are frequently resorted to save time and resources [13-16]. Optimization of process operating conditions by the response surface methodology (RSM) has become a widely preferred approach in order to have a profound understanding on the main and interaction effects of factors on responses [17-19]. Response surface method has been used to optimize not only the experimental data but also the simulation results [20].

In this study, utilization of the waste stream of a process, producing $\mathrm{Na}_{2} \mathrm{CO}_{3}$ and $\mathrm{NaHCO}_{3}$ from trona, in $\mathrm{SO}_{2}$ removal from flue gas by wet techniques was investigated through ChemCad simulations. Among many other operating parameters, feed rate of $\mathrm{SO}_{2}$, flue gas entrance temperature and sorbent feed rate were selected as independent parameters and their effects on $\mathrm{SO}_{2}$ removal were identified by RSM approach using the central composite design (CCD).

Taking into account about 8\% yearly increase in Turkey's energy demand of which almost $75 \%$ originates from thermal power plants, it is straight forward to comprehend that $\mathrm{SO}_{2}$ removal by using the waste stream of natural soda ash process which itself requires an investment for disposal would be highly profitable. Additionally, this study concludes that $\mathrm{SO}_{2}$ emission rates below the limits set by the environmental regulations for power plants of capacities between 100 and $300 \mathrm{MW}$ using solid fuels are indeed attainable under the conditions tested.

\section{EXPERIMENTAL}

Sorbent solutions of compositions to be used in flue gas desulfurization were supplied by the Soda Ash and Sodium Bicarbonate Production Plant of Eti Soda Inc. located 
in Beypazar1 region of Ankara, Turkey. The solution was composed of a mixture of downstreams from monohydrate and decahydrate centrifuges of heavy soda (dehydrated $\mathrm{Na}_{2} \mathrm{CO}_{3}$ ) unit. The flow rate of the waste stream containing water, $\mathrm{Na}_{2} \mathrm{CO}_{3}, \mathrm{NaHCO}_{3}$ (Table 1) was $50 \mathrm{~m}^{3} \mathrm{~h}$. The waste was regularly stored in solution reservoirs or used in solution mining to push underground trona ore to the surface.

Table 1

Properties of natural soda ash production process waste

\begin{tabular}{|l|c|}
\hline \multicolumn{1}{|c|}{ Parameter } & Value \\
\hline Temperature & $20{ }^{\circ} \mathrm{C}$ \\
\hline Density & $1.3 \mathrm{~g} / \mathrm{cm}^{3}$ \\
\hline Concentration of $\mathrm{Na}_{2} \mathrm{CO}_{3}$ & $3.056 \mathrm{~mol} / \mathrm{dm}^{3}$ \\
\hline Concentration of $\mathrm{NaHCO}_{3}$ & $0.321 \mathrm{~mol} / \mathrm{dm}^{3}$ \\
\hline
\end{tabular}

Simulation studies were initiated with real process data regarding solution compositions and flow rates. However, ChemCad simulation software sets some limits for the sorbent flow rate based on the gaseous feed rate to the absorption tower. In other words, the sorbent flow rate was too high and resulted in divergence when the real process data were used for simulation. Therefore the flow rate of the sorbent stream was decreased by $10 \%$ without altering its composition. Furthermore, water content of the waste stream was insufficient to dissolve $\mathrm{Na}_{2} \mathrm{CO}_{3}$ and $\mathrm{NaHCO}_{3}$ and some dilution was carried out according to solubility data of $\mathrm{Na}_{2} \mathrm{CO}_{3}$ and $\mathrm{NaHCO}_{3}$ at $20{ }^{\circ} \mathrm{C}$ being $215 \mathrm{~g} / \mathrm{dm}^{3}$ and $96 \mathrm{~g} / \mathrm{dm}^{3}$, respectively. The calorific value and composition of lignite originating from a $150 \mathrm{MW}$ power plant operating at $35 \%$ burning efficiency with $30 \%$ excess air are given in Table 2. Compositions of sorbent solution and flue gas fed to the absorption tower are given in Tables 3 and 4, respectively.

Table 2

Results of proximate and ultimate analysis of lignite used in the power plant [wt. \%]

\begin{tabular}{|l|c|}
\hline \multicolumn{1}{|c|}{ Component } & Value \\
\hline $\mathrm{C}$ & 25.12 \\
\hline $\mathrm{H}$ & 2.01 \\
\hline $\mathrm{S}$ & 1.87 \\
\hline $\mathrm{O}$ & 8.49 \\
\hline $\mathrm{N}$ & 0.76 \\
\hline Ash & 41.89 \\
\hline Humidity & 19.86 \\
\hline Lower calorific value, $\mathrm{kcal} / \mathrm{kg}$ & 2248 \\
\hline
\end{tabular}


Table 3

Composition of the waste sorbent solution fed to the absorption column

\begin{tabular}{|l|c|c|}
\hline Component & $\begin{array}{c}\text { Flow rate } \\
{[\mathrm{kmol} / \mathrm{h}]}\end{array}$ & $\begin{array}{c}\text { Concentration } \\
{[\mathrm{mol} \%]}\end{array}$ \\
\hline $\mathrm{Na}_{2} \mathrm{CO}_{3}$ & 15.283 & 0.320 \\
\hline $\mathrm{NaHCO}_{3}$ & 1.607 & 0.034 \\
\hline $\mathrm{H}_{2} \mathrm{O}$ & 4745 & 99.646 \\
\hline
\end{tabular}

Table 4

Composition of the flue gas fed to the absorption column

\begin{tabular}{|l|c|c|}
\hline Component & $\begin{array}{c}\text { Flow rate } \\
{[\mathrm{kmol} / \mathrm{h}]}\end{array}$ & $\begin{array}{c}\text { Concentration } \\
{[\mathrm{mol} \%]}\end{array}$ \\
\hline $\mathrm{CO}_{2}$ & 1023.59 & 11.31 \\
\hline $\mathrm{SO}_{2}$ & 28.06 & 0.31 \\
\hline $\mathrm{N}_{2}$ & 5727.97 & 63.29 \\
\hline $\mathrm{H}_{2} \mathrm{O}$ & 1919.58 & 21.21 \\
\hline $\mathrm{O}_{2}$ & 351.15 & 3.88 \\
\hline Total & 9050.35 & 100.00 \\
\hline
\end{tabular}

Simulation studies were carried out through wet desulfurization processes where $\mathrm{CaCO}_{3}, \mathrm{Na}_{2} \mathrm{CO}_{3}$ and waste stream of natural soda ash production unit were used as the sorbents. In order to include chemical reactions, vapor-liquid equilibrium model was selected from the SCDS template for spray tower having neither a reboiler nor a condenser. As highly common in the industrial processes, sorbent stream was introduced from the top and the flue gas was introduced from the bottom of the absorption tower shown schematically in Fig. 1. Refined gas was released from the top of the tower while sulfite was drained from the bottom. SCDS is a multistage vapor-liquid equilibrium module which is able to compute single column calculations including distillation columns, absorbers and scrubbers. Basically, non-ideal distribution coefficients $K$ are designed for the simulation of chemical systems. Derivative of each equation is calculated by the Newton-Raphson convergence method.

Optimum values of operating parameters for $\mathrm{SO}_{2}$ removal process were determined by the response surface method based on the central composite design technique. Central composite design for three factors with 20 working points were applied in simulation studies. The $\mathrm{SO}_{2}$ flow rate, flue gas entrance temperature and $\mathrm{H}_{2} \mathrm{O}$ flow rate for the sorbent solution have been selected as the independent variables. The $\mathrm{SO}_{2}$ removal efficiency was the response variable calculated based on the $\mathrm{SO}_{2}$ contents of in and out flows to and from the absorption column using Eq. (1). Actual and coded levels of independent variables are listed in Table 5. 


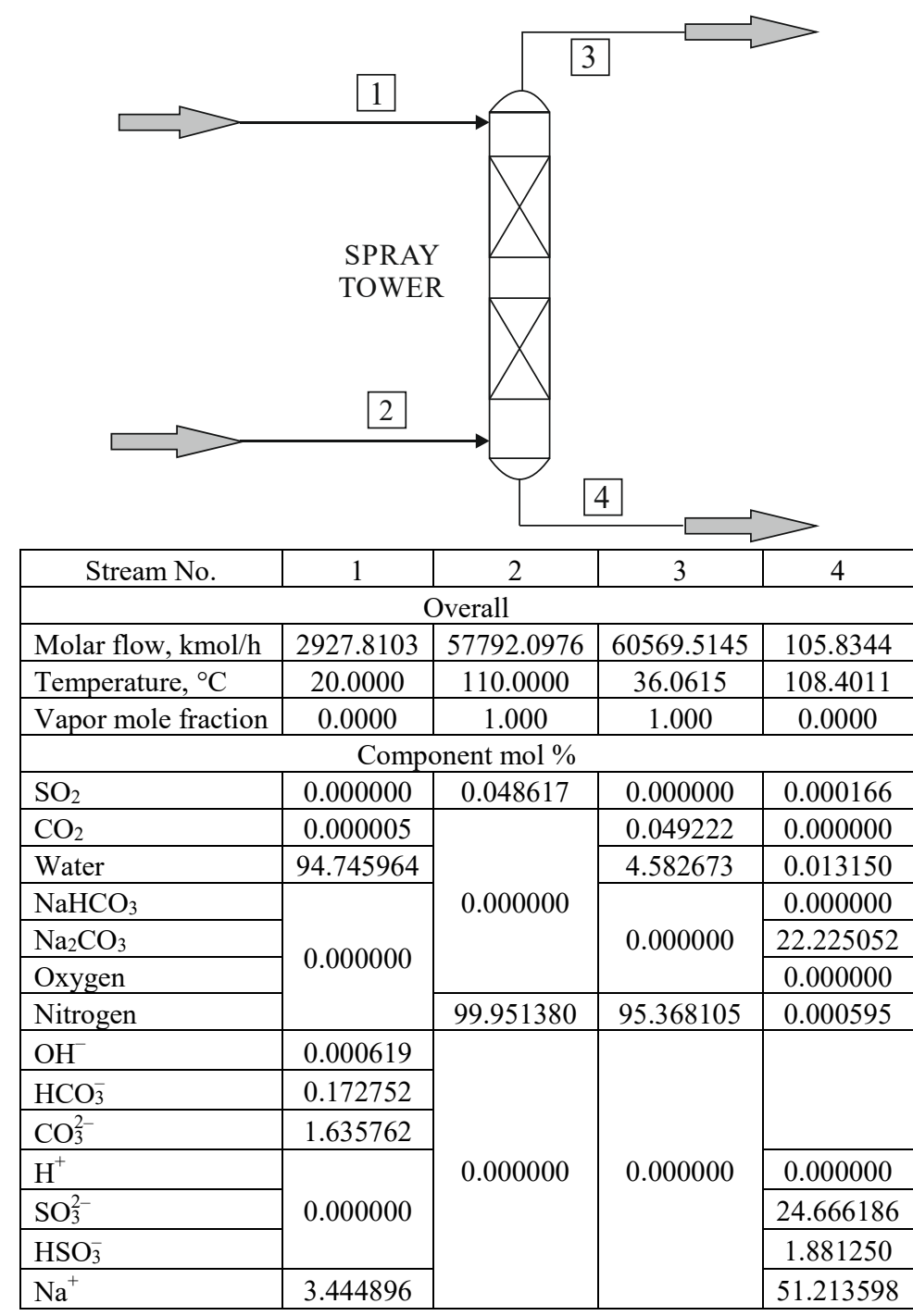

Fig. 1. Sample of absorption column model

$$
R_{\mathrm{SO}_{2}}=\frac{F_{\mathrm{SO}_{2}}-F_{\mathrm{SO}_{2 \text { out }}}}{F_{\mathrm{SO}_{2}}} \times 100
$$

where $R_{\mathrm{SO}_{2}}$ is the removal efficiency of $\mathrm{SO}_{2}, \%, F_{\mathrm{SO}_{2}}$ - the flue gas (FG) inlet flow rate, $\mathrm{kmol} / \mathrm{h}, F_{\mathrm{SO}_{20 u t}}-$ flue gas outlet flow rate, $\mathrm{kmol} / \mathrm{h}$. 
Table 5

Actual and coded levels of the independent variables used in the central composite design

\begin{tabular}{|c|l|c|c|c|c|c|}
\hline \multicolumn{2}{|c|}{ Factor } & -1 & 0 & 1 & $-\alpha$ & $\alpha$ \\
\hline $\mathrm{A}$ & $F_{\mathrm{SO}_{2}}, \mathrm{kmol} / \mathrm{h}$ & 28.10 & 67.64 & 107.18 & 1.14 & 134.14 \\
\hline $\mathrm{B}$ & $T_{F G},{ }^{\circ} \mathrm{C}$ & 50 & 80 & 110 & 29.55 & 130.45 \\
\hline $\mathrm{C}$ & $\left.F_{\mathrm{H}_{2} \mathrm{O}}, \mathrm{kmol} / \mathrm{h}\right)$ & 3200 & 3972.50 & 4745 & 2673.32 & 5271.68 \\
\hline
\end{tabular}

System components have been selected according to the sorbent used in the absorption tower. The electrolyte model was found to be appropriate to simulate absorption events which take place through ionization reactions and the Pitzer model was used for this purpose. Chemical reactions of the model are given as follows:

$$
\begin{gathered}
\mathrm{H}_{2} \mathrm{O} \rightarrow \mathrm{H}^{+}+\mathrm{OH}^{-} \\
\mathrm{SO}_{2}+\mathrm{H}_{2} \mathrm{O} \rightarrow \mathrm{H}^{+}+\mathrm{HSO}_{3}^{-} \\
\mathrm{HSO}_{3}^{-} \rightarrow \mathrm{H}^{+}+\mathrm{SO}_{3}^{2-} \\
\mathrm{HCO}_{3}^{-} \rightarrow \mathrm{H}^{+}+\mathrm{CO}_{3}^{2-} \\
\mathrm{CO}_{2}+\mathrm{H}_{2} \mathrm{O} \rightarrow \mathrm{H}^{+}+\mathrm{HCO}_{3}^{-} \\
\mathrm{CaCO}_{3} \rightarrow \mathrm{Ca}^{2+}+\mathrm{CO}_{3}^{2-} \\
\mathrm{Na}_{2} \mathrm{CO}_{3} \rightarrow 2 \mathrm{Na}^{+}+\mathrm{CO}_{3}^{2-} \\
\mathrm{NaHCO}_{3} \rightarrow \mathrm{Na}^{+}+\mathrm{HCO}_{3}^{-}
\end{gathered}
$$

\section{RESULTS}

First of all effects of $\mathrm{SO}_{2}$ content in the flue gas on removal efficiencies were tested using three different sorbent solutions in order to compare their $\mathrm{SO}_{2}$ removal performances. Flue gas temperature and compositions of sorbent solution used for this purpose are given in Table 6. Figure 2 illustrates some reduction in $\mathrm{SO}_{2}$ removal with an increase in $\mathrm{SO}_{2}$ contents of the flue gas for all sorbent solutions. Flue gas entrance temperature is also an important parameter since it has profound effect on ionization and solution reactions in the absorption tower. Figure 3 presents the results of simulation performed at various temperatures of flue gas given in Table 7. As can be deduced from Fig. 3, 
solutions containing $\mathrm{CaCO}_{3}$ cannot be used for removal above $100{ }^{\circ} \mathrm{C}$ while $\mathrm{Na}_{2} \mathrm{CO}_{3}$ and waste sorbent solutions are still effective up to $160^{\circ} \mathrm{C}$.

Table 6

Flue gas (FG) inlet temperature and composition of the sorbent solution

for the simulations examining the effects of $\mathrm{SO}_{2}$ flow rate

\begin{tabular}{|c|l|c|}
\hline \multirow{2}{*}{$T_{\mathrm{FG}}\left[{ }^{\circ} \mathrm{C}\right]$} & \multicolumn{2}{|c|}{ Sorbent solution } \\
\cline { 2 - 3 } & \multicolumn{1}{|c|}{ Component } & Content $[\mathrm{mol} \%]$ \\
\hline \multirow{3}{*}{40} & $\mathrm{CaCO}_{3}$ & 1.87 \\
\cline { 2 - 3 } & $\mathrm{Na}_{2} \mathrm{CO}_{3}$ & 1.87 \\
\cline { 2 - 3 } & waste & 0.36 \\
\hline
\end{tabular}

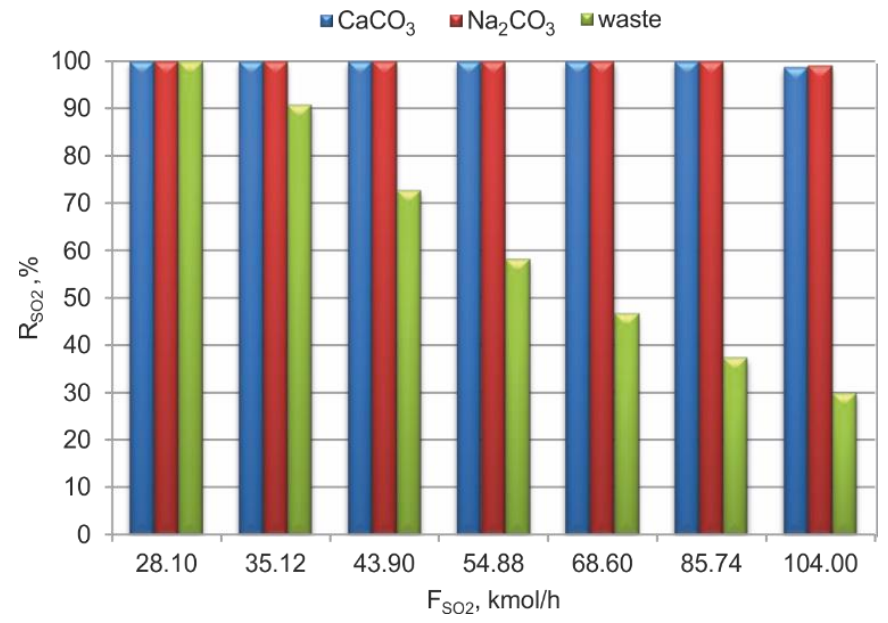

Fig. 2. Effect of $\mathrm{SO}_{2}$ flow rate on $\mathrm{SO}_{2}$ removal

Table 7

Flue gas $\mathrm{SO}_{2}$ flow rate and composition of the sorbent solutions

\begin{tabular}{|c|c|c|}
\hline \multirow{2}{*}{$\begin{array}{c}F_{\mathrm{SO}_{2}} \\
{[\mathrm{kmol} / \mathrm{h}]}\end{array}$} & \multicolumn{2}{|c|}{ Sorbent solution } \\
\hline & Component & Content [mol \%] \\
\hline 28.1 & $\mathrm{CaCO}_{3}$ & 1.87 \\
\hline 28.1 & $\mathrm{Na}_{2} \mathrm{CO}_{3}$ & 1.87 \\
\hline 28.1 & waste & 0.36 \\
\hline
\end{tabular}

Simulation results presented in Fig. 4 illustrate the effect of sorbent compositions on $\mathrm{SO}_{2}$ removal when the $\mathrm{SO}_{2}$ flow rate in flue gas was $28.1 \mathrm{kmol} / \mathrm{h}$ and flue gas temperature was $40{ }^{\circ} \mathrm{C}$. According to these results, decrease in compositions of waste and $\mathrm{Na}_{2} \mathrm{CO}_{3}$ solutions in other words increase in $\mathrm{H}_{2} \mathrm{O}$ flow rate lowers $\mathrm{SO}_{2}$ removal severely. 
Furthermore dilute solutions of waste and $\mathrm{Na}_{2} \mathrm{CO}_{3}$ show better performance compared to $\mathrm{CaCO}_{3}$ solutions.

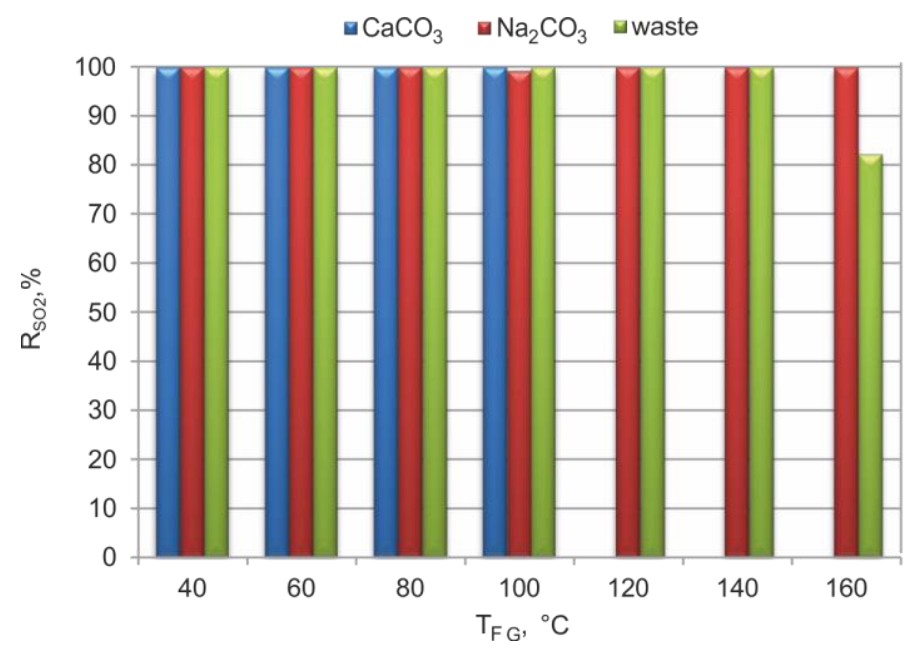

Fig. 3. Effect of flue gas temperature on $\mathrm{SO}_{2}$ removal

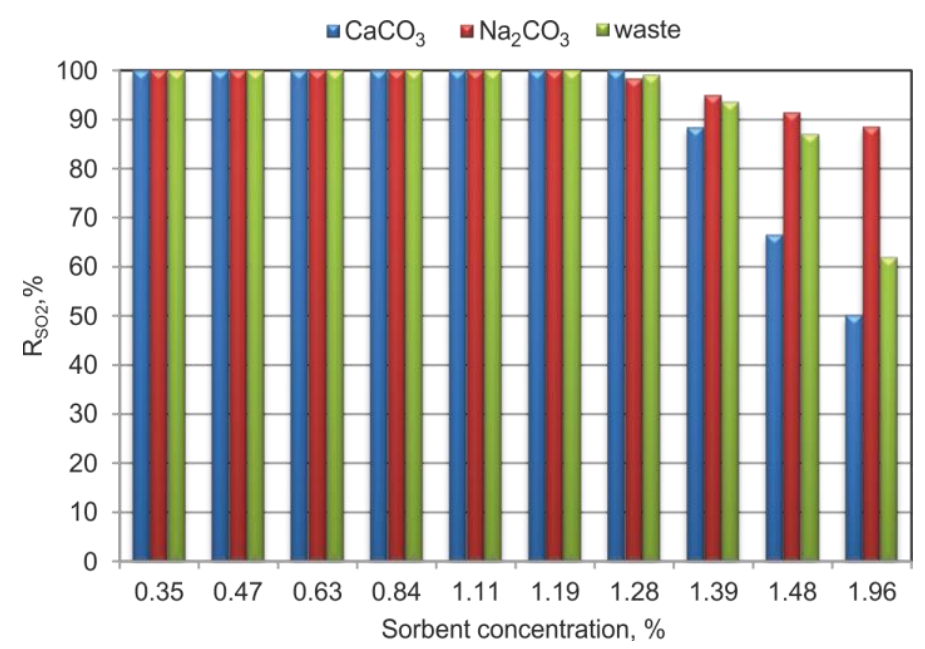

Fig. 4. Effect of sorbent concentration on $\mathrm{SO}_{2}$ removal

Response values for $\mathrm{SO}_{2}$ removal obtained at operating conditions given in Table 8 have been computed using Eq. (1). The regression coefficient, adj- $R^{2}$ and pred- $R^{2}$ values were calculated to be $0.8656,0.84$ and 0.774 , respectively:

$$
R_{\mathrm{SO}_{2}}, \%=102.57535-0.74173 F_{\mathrm{SO}_{2}}-0.063055 T_{\mathrm{FG}}+1.83584 \times 10^{-3} F_{\mathrm{H}_{2} \mathrm{O}}
$$


Table 8

Operating points and their coded values for central composite design and the responses obtained from ChemCad simulations

\begin{tabular}{|c|c|c|c|c|c|c|c|}
\hline Run & \multicolumn{2}{|c|}{$\begin{array}{c}F_{\mathrm{SO}_{2}} \\
{[\mathrm{kmol} / \mathrm{h}]}\end{array}$} & \multicolumn{2}{|c|}{$\begin{array}{c}T_{\mathrm{FG}} \\
{\left[{ }^{\circ} \mathrm{C}\right]}\end{array}$} & \multicolumn{2}{|c|}{$\begin{array}{c}F_{\mathrm{H}_{2} \mathrm{O}} \\
{[\mathrm{kmol} / \mathrm{h}]}\end{array}$} & $\begin{array}{c}R_{\mathrm{SO}_{2}} \\
{[\%]}\end{array}$ \\
\hline 1 & 0 & 67.64 & 0 & 80 & 0 & 3972.50 & 47.1332 \\
\hline 2 & 1 & 107.18 & -1 & 50 & -1 & 3200 & 29.9769 \\
\hline 3 & 0 & 67.64 & 0 & 80 & 0 & 3972.50 & 47.1332 \\
\hline 4 & $\alpha$ & 134.14 & 0 & 80 & 0 & 3972.50 & 23.9235 \\
\hline 5 & 0 & 67.64 & 0 & 80 & 0 & 3972.50 & 47.1332 \\
\hline 6 & 0 & 67.64 & 0 & 80 & $-\alpha$ & 2673.32 & 45.1633 \\
\hline 7 & 0 & 67.64 & 0 & 80 & 0 & 3972.50 & 47.1332 \\
\hline 8 & -1 & 28.10 & -1 & 50 & -1 & 3200 & 100 \\
\hline 9 & 0 & 67.64 & 0 & 80 & $\alpha$ & 5271.68 & 47.442 \\
\hline 10 & 1 & 107.18 & 1 & 110 & 1 & 4745 & 29.7805 \\
\hline 11 & 0 & 67.64 & $-\alpha$ & 29.55 & 0 & 3972.50 & 47.6662 \\
\hline 12 & 0 & 67.64 & 0 & 80 & 0 & 3972.50 & 47.1332 \\
\hline 13 & $-\alpha$ & 1.14 & 0 & 80 & 0 & 3972.50 & 100 \\
\hline 14 & -1 & 28.10 & 1 & 110 & 1 & 4745 & 100 \\
\hline 15 & -1 & 28.10 & -1 & 50 & 1 & 4745 & 100 \\
\hline 16 & 1 & 107.18 & 1 & 110 & -1 & 3200 & 25.9639 \\
\hline 17 & 0 & 67.64 & $\alpha$ & 130.45 & 0 & 3972.50 & 41.7763 \\
\hline 18 & 1 & 107.18 & -1 & 50 & 1 & 4745 & 30.1347 \\
\hline 19 & -1 & 28.10 & 1 & 110 & -1 & 3200 & 88.4387 \\
\hline 20 & 0 & 67.64 & 0 & 80 & 0 & 3972.50 & 47.1332 \\
\hline
\end{tabular}

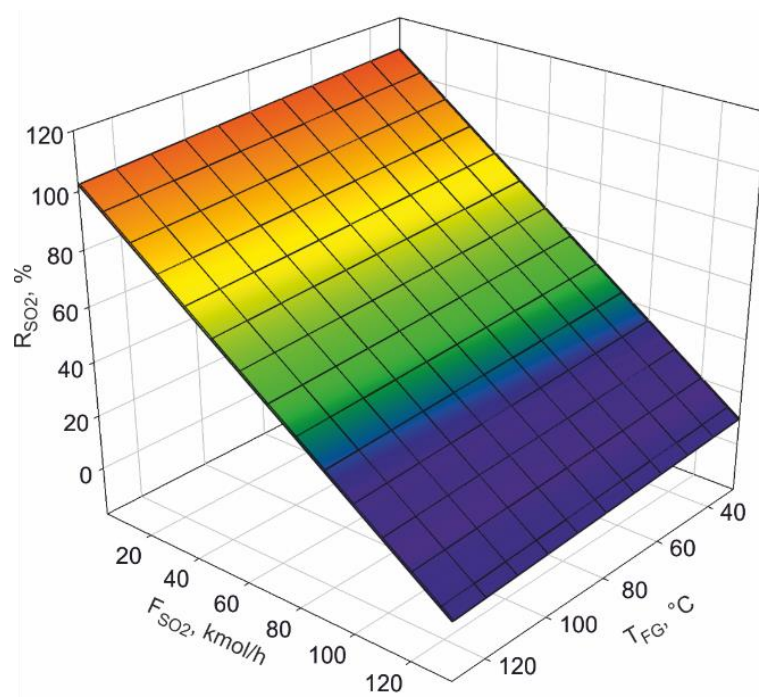

Fig. 5. Response surface representing the effects of $\mathrm{FSO}_{2}$ and $T_{\mathrm{FG}}$ on $\mathrm{SO}_{2}$ removal $\left(F_{\mathrm{H}_{2} \mathrm{O}}=4745 \mathrm{kmol} / \mathrm{h}\right)$ 


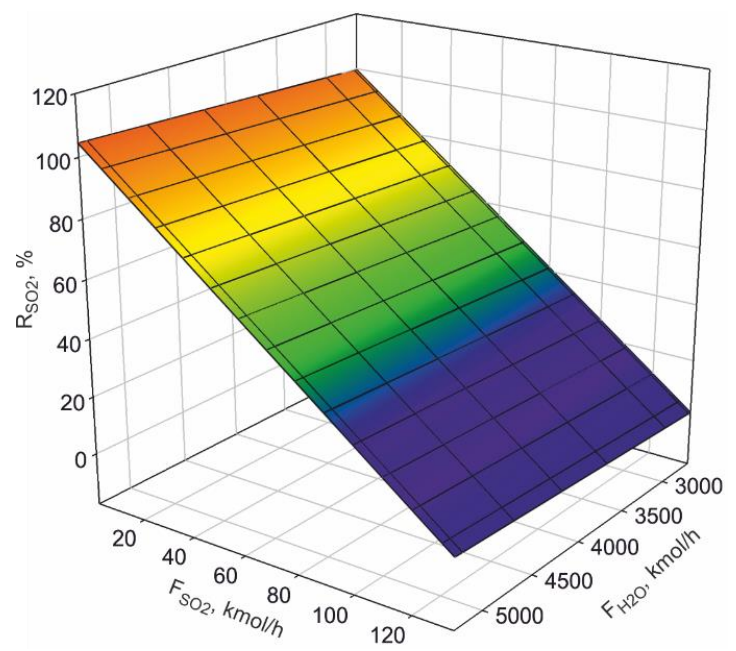

Fig. 6. Response surface representing the effects of $F_{\mathrm{SO}_{2}}$ and $F_{\mathrm{H}_{2} \mathrm{O}}$ on $\mathrm{SO}_{2}$ removal $\left(T_{\mathrm{FG}}=110^{\circ} \mathrm{C}\right)$

Response surface diagrams presented in Figs. 5 and 6 illustrate the effects of $\mathrm{SO}_{2}$ content and temperature of the flue gas entering the absorption tower, on $\mathrm{SO}_{2}$ removal. The figures (based on Eq. (10)) have been plotted for the maximum value of the third independent variable. Based on these results, the optimum values of independent variables yielding highest $\mathrm{SO}_{2}$ have been determined as $F_{\mathrm{SO}_{2}}=28.10 \mathrm{kmol} / \mathrm{h}, T_{\mathrm{FG}}=50{ }^{\circ} \mathrm{C}$ and $F_{\mathrm{H}_{2} \mathrm{O}}=4745 \mathrm{kmol} / \mathrm{h}$.

Waste solutions of 2-10 wt. \% have been tested to obtain higher $\mathrm{SO}_{2}$ removal efficiencies and results are listed in Table 9. Simulation studies for $\mathrm{SO}_{2}$ removal based on stoichiometrically calculated flue gas compositions of a $150 \mathrm{MW}$ thermal power plant have shown that $\mathrm{SO}_{2}$ content of the refined gas can be lowered below the limit value of $1300 \mathrm{mg} / \mathrm{Nm}^{3}$ set by the environmental regulations by using the waste composition of $8 \mathrm{wt}$. \%.

Table 9

$\mathrm{SO}_{2}$ contents of the gas streams entering and leaving the absorption column and corresponding $\mathrm{SO}_{2}$ removal yields for various waste compositions

\begin{tabular}{|c|c|c|c|c|c|c|c|}
\hline $\begin{array}{c}F_{\mathrm{Na}_{2} \mathrm{CO}_{3}} \\
{[\mathrm{kmol} / \mathrm{h}]}\end{array}$ & $\begin{array}{c}F_{\mathrm{NaHCO}_{3}} \\
{[\mathrm{kmol} / \mathrm{h}]}\end{array}$ & $\begin{array}{c}F_{\mathrm{H}_{2} \mathrm{O}} \\
{[\mathrm{kmol} / \mathrm{h}]}\end{array}$ & $\begin{array}{c}\text { Waste } \\
\text { composition } \\
{[\text { wt. \%] }}\end{array}$ & $\begin{array}{c}F_{\mathrm{SO}_{2}} \\
{[\mathrm{kmol} / \mathrm{h}]}\end{array}$ & $\begin{array}{c}F_{\mathrm{SO}_{2} \mathrm{out}} \\
{[\mathrm{kmol} / \mathrm{h}]}\end{array}$ & $\begin{array}{c}F_{\mathrm{SO}_{2} \text { out }} \\
{\left[\mathrm{mg} / \mathrm{Nm}{ }^{3}\right]}\end{array}$ & $\begin{array}{c}R \mathrm{SO}_{2} \\
{[\%]}\end{array}$ \\
\hline 15.283 & 1.607 & 4745.00 & 2 & 93.99 & 62.19321 & 5464.61 & 33.83 \\
\hline 19.104 & 2.009 & 4745.00 & 3 & 93.99 & 54.45699 & 4783.88 & 42.06 \\
\hline 38.208 & 4.018 & 4745.00 & 5 & 93.99 & 17.36109 & 1524.62 & 81.53 \\
\hline 45.849 & 4.8213 & 4745.00 & 6 & 93.99 & 3.304437 & 290.13 & 96.48 \\
\hline 61.132 & 6.4284 & 4745.00 & 8 & 93.99 & $6.67 \mathrm{E}-13$ & $5.86 \mathrm{E}-11$ & 100.00 \\
\hline 84.057 & 8.839 & 4745.00 & 10 & 93.99 & $7.52 \mathrm{E}-08$ & $6.59 \mathrm{E}-06$ & 100.00 \\
\hline
\end{tabular}




\section{CONCLUSIONS}

Due to growing energy demands owing to industrial and technological developments, fossil fuels will continue to play important roles, as in the past, in order to attain sustainable progress with safe and reliable energy sources. Emerging desulfurization techniques and newly discovered sorbents will enable the use of fossil fuels having high sulfur contents in energy production. In this study, waste stream of a natural soda ash production process has been tested in terms of $\mathrm{SO}_{2}$ removal from flue gas and demonstrated to be an alternative to widely used limestone. In addition, a waste stream which itself requires an extra cost and investment for elimination is shown to be disposed of in the same process.

ChemCad simulations were performed using waste solutions of $2 \mathrm{wt}$. \% to evaluate the effects of $\mathrm{SO}_{2}$ loading, flue gas temperature and $\mathrm{H}_{2} \mathrm{O}$ feed rate on the $\mathrm{SO}_{2}$ removal efficiency. Increase in $\mathrm{SO}_{2}$ content of the flue gas resulted in decrease in the removal efficiency, and $100 \%$ removal was attained when maximum flow rate of $\mathrm{SO}_{2}$ was $32 \mathrm{kmol} / \mathrm{h}$. In terms of flue gas inlet temperature, $100 \%$ removal was attainable up to $140{ }^{\circ} \mathrm{C}$ but efficiencies decreased to 96.66 and $82.18 \%$, respectively, as the inlet temperature of flue gas was raised to $150{ }^{\circ} \mathrm{C}$ and $160{ }^{\circ} \mathrm{C}$. Reducing the $\mathrm{H}_{2} \mathrm{O}$ content of the waste solution resulted in lower $\mathrm{SO}_{2}$ removal efficiencies. Down to $1400 \mathrm{kmol} / \mathrm{h} \mathrm{H}_{2} \mathrm{O}$ feed rates, $100 \%$ removal was shown to be attainable depending on values of the other independent parameters.

The solution containing $2 \%$ waste with $15.283 \mathrm{kmol} / \mathrm{h} \mathrm{Na} \mathrm{NO}_{3}, 1.607 \mathrm{kmol} / \mathrm{h}$ $\mathrm{NaHCO}_{3}$ and $4745 \mathrm{kmol} / \mathrm{h} \mathrm{H}_{2} \mathrm{O}$ flow rates was used as the sorbent and shown to result in $33.83 \% \mathrm{SO}_{2}$ removal. Solutions with higher waste contents were tested in order to increase removal efficiency and it was demonstrated that increasing the mass percent of the waste in the sorbent solution up to $8-10 \mathrm{wt}$ \% results in $100 \% \mathrm{SO}_{2}$ removal while 6 wt. \% waste solutions were just as effective to reduce the $\mathrm{SO}_{2}$ content in the refined gas below the regulatory limits of $1300 \mathrm{mg} / \mathrm{Nm}^{3}$. It can be finally claimed that natural soda ash production process waste can be utilized in flue gas desulfurization. In order to attain required efficiencies of $\mathrm{SO}_{2}$ removal, the capacity of the power plant and quality of the fuel have to be considered carefully to adjust the concentration of the waste solution entering the absorption tower.

\section{REFERENCES}

[1] ÖzyoĞURAn A., Altun-ÇıftçıoĞlu G.A., KocAtepe N., Ersoy-MeriçBoyu A., Effect of magnesium ions on the sulphate ion capacity of limestone slurry, J. Environ. Sci. Health A, 2006, 41 (9), 1955.

[2] StOKer H.S., SeAger S.L., Environmental Chemistry. Air and Water Pollution, Scott Foresman, Illinois 1972.

[3] Mahajan S.P., Pollution Control in Process Industries, McGraw Hill, New Delhi 1985.

[4] Topal H., Lime/lime-sugar waste pulp mixture usage for reduction of $\mathrm{SO}_{2}$ emissions caused by domestic heating, J. Fac. Eng. Arch. Gazi Univ., 2000, 15 (1), 15. 
[5] Flue Gas Desulfurisation (FGD) Technologies, Cleaner Coal Technology Programme, Technology Status Report 012, Department of Trade and Industry, London 2000.

[6] Wu C., Khang S.-J., KeEner T.C., LeE S.-K., A model for sodium bicarbonate duct injection flue gas desulfurization, Adv. Environ. Res., 2004, 8, 655.

[7] LiU Y., Bisson T.M., YANG H., XU Z., Recent developments in novel sorbent for flue gas cleanup, Fuel Process. Technol., 2010, 91, 1175.

[8] Ogenga D.O., Mbarawa M.M., Lee K.T., Mohamed A.R., Dahlan I., Sulfur dioxide removal using South African limestone/siliceous materials, Fuel, 2010, 89, 2549.

[9] Hongliang G., Caiting L., Guangming Z., Wei Z., Lin S., Shanhong L., Yanan Z., Xiaopeng F., QINGBO W., XIN S., Prediction and experimental validation studies of wet flue gas desulfurization with a novel type pcf device based on limestone-gypsum, Energ. Fuel, 2010, 24, 4944.

[10] Hongliang G., Caiting L., Guangming Z., Wei Z., Lin S., Shanhong L., Yanan Z., Xiaopeng F., QINGBO W., XIN S., Flue gas desulfurization based on limestone-gypsum with a novel type PCF device, Sep. Purif. Technol., 2011, 76, 253.

[11] ReCelu T., Golob J., Equilibrium and mass transfer in the $\mathrm{Ca}^{2+}-\mathrm{SO}_{2}-\mathrm{H}_{2} \mathrm{O}$ system for the analysis of the flue gas desulfurization process, Process Saf. Environ., 2004, 82 (B5), 371.

[12] ERDÖL-AYdin N., NASÜN-SAYGILI G., Modelling of trona based spray dry scrubbing of $\mathrm{SO}_{2}$, Chem. Eng. J., 2007,126, 45.

[13] ValderRama J.O., Toselli L.A., Faúndez C.A., Advances on modeling and simulation of alcoholic distillation. Part 1. Thermodynamic modeling, Food Bioprod. Process., 2012, 90, 819.

[14] LAM K.F., SORENSEN E., GAVRIILIDIS A., Towards an understanding of the effects of operating conditions on separation by microfluidic distillation, Chem. Eng. Sci., 2011, 66, 2098.

[15] MaXim V., Cormos C.C., CoRmos A.M., AGACHI S., Mathematical modeling and simulation of gasification processes with carbon capture and storage (CCS) for energy vectors poly-generation, 20th EuropeanSymposium on Computer Aided Process Engineering - ESCAPE20, 2010, 28, 697.

[16] Calabro A., Deiana P., Fiorini P., Girardri. G., Stendardo S., Possible optimal configurations for the ZECOMIX high efficiency, Energy, 2008, 33, 952.

[17] Arami-Niya A., Daud W.M.A.W., Mualli F.S., Abnisa F., Shafeeyan M.S., Production of microporous palm shell based activated carbon for methane adsorption: modeling and optimization using response surface methodology, Chem. Eng. Res. Des., 2011, 90, 776.

[18] Dahlan I., Ahmad A., Fadly M., Lee K.T., Kamaruddin A.H., Mohamed A.R., Parameters optimization of rice husk ash (RHA)/CaO/CeO 2 sorbent for predicting $\mathrm{SO}_{2} / \mathrm{NO}$ sorption capacity using response surface and neural network models, J. Hazard. Mater., 2010, 178, 249.

[19] Soloman P.A., Basha C.A., Velan M., Balasubramanian N., Marimuthu P., Augmentation of biodegradibility of pulp and paper industry waste water by electrochemical pre-treatment and optimization by RSM, Sep. Purif. Technol., 2009, 69, 109.

[20] Bahloul R., Mkaddem A., SANto D., Potiron A., Sheet metal blending optimization using numerical simulation and design of experiments, Int. J. Mech. Sci., 2006, 48, 991. 